\title{
SHORTAGES OF SCIENTIFIC PERSONNEL IN EUROPEAN COUNTRIES IN PROCESS OF DEVELOPMENT
}

\begin{abstract}
$\mathrm{T}$ HE shortage of scientific personnel is common to all European countries, even those which have a long tradition of scientific and technical development backed by powerful resources. Industrialized countries face ever-increasing requirements, while countries which are primarily agricultural and commercial now feel the need to build up their industrial potential in order to compete with the rest of Europe and raise their standard of living.

For such countries the shortage of scientific personnel is particularly acute and raises problems which are most urgent. Chief of these, according to Rector Capelle, director-general of the Institut National des Sciences appliquées, in a recent issue of European Productivity (No. 35; April 1960), are : training of teachers of sciencs and technical subjects; broadening of secondary education to include technical subjects ; training of engineers; development of scientific research; and the development of university-industry relations.

Industry's demand for scientists and technicians and the generous salaries offered are frequently a severe handicap to the recruitment of science teachers. Teachers' salaries must be raised if the necessary teachers of high calibre are to be found for the rising school population. This applies not only to secondary schools and technical colleges but also to the universities themselves, where too often a professor's salary at the end of his career is no more than that offered to his students on entering industry. A further demand for teachers comes from industry itself, where the old system of training skilled workers and technicians on the job must be supplemented by proper training courses providing the appropriate
\end{abstract} general education at each level.

In order to persuade more and more young psople to become technicians or engineers, and to attract children from families obsessed with the idea of classical education, the traditional secondary education should be broadened to include technical subjects laying the foundations of a technical humanism supplementing, and in no way conflicting, with traditional humanism. In all secondary education, the laboratory and the workshop should now be used as instruments of learning in the same way as books, which still have too much of a monopoly.

In countries in process of development, engineers are trained to a high level and in physical conditions in no way inferior to those prevailing in countries with a long-established technological tradition. Technical faculties or universities training engineers are compelled to make a strict selection of candidates, but this is a good guarantee of success. Many students who cannot find a place in the higher educational establishments of their own country go to a foreign technical university. This additional supply of engineers--sometimes as much as 50 per cent-is not always appreciated.

The methodical increase of means of production implies making provision for research. It might seem enough to leave the responsibility for research to the countries best equipped for it. This would in the end be detrimental to young industries. The organization of scientific research will become a vital necessity for all countries and will call for the combination of all human and material resources ; the Government, the universities and industry must all co-operate, and here the university can play a leading part without any loss of dignity or independence.

Applied scientific research is one of the links to be established between universities and industry, two worlds which are much too far apart in most countries in process of development. Industry should not be governed purely by a shopkeeper mentality.

\section{EAST AFRICAN VIRUS RESEARCH INSTITUTE, ENTEBBE}

$\mathrm{T}$ HE report of the East African Virus Research Institute for July, 1958 June, 1959 by the acting director, J. D. Gillett, shows that the approach to virus studies is still essentially ecological-using the word in its widest sense to cover interaction between virus host and environment (Pp. $\mathrm{ii}+49$. (Nairobi : Government Printer, 1960.) 5s.). Attention has again been confined to those viruses which are transmitted to man by arthropods ; 60 different viruses are now known or suspected of being arthropod borne. Mosquitoes are involved or suspected in the transmission of no less than 48 of these, and man has been implicated in 47 of them. Twenty-six of these viruses have been found in Africa, 14 of them coming from East Africa itself. Eleven of the 14 East African viruses were originally isolated in the Institute, three of them during the current year.

The isolation of viruses from the living vertebrate host, including man, is often missed because of the transient nature of the viræmia. Nevertheless, in addition to several strains isolated during an outbreak of yellow fever in the Congo, five isolations have been made in East Africa from man; three of these in the period under review were from members of the Institute staff. Three of the five East African isolates appear to be new agents, or at least new strains. One of the others was an accidental laboratory infection of Wesselbron virus, and opportunity was taken of keeping full clinical and physiological records of the course of this very unpleasant disease.

More than 20,000 wild mosquitoes were caught and processed in the laboratory, but no virus isolations were made. This is the second year in which this usually fruitful source of virus has been unproductive.

The work started the previous year on a possible vaccine against Nairobi sheep disease, the virus of which apparently involves man as well as sheep, has been further developed. The first field-trial with the new experimental vaccine carried out in collaboration with the East African Trypanosomiasis Research Organization at Sukulu has fullv iustified earlier hopes. 
Antibody surveys in local residents have been extended by increasing the number of sera tested and by widening the spectrum of viruses used. P'ositive reactions have been found in all but one of the ten agents used. Surveys of birds were started again, but no positive results have been obtained.

Results of the antibody surveys on a largo numbor of hippopotamus sera have given unexpected results, and are difficult to interpret. A high proportion of the sera has given positive neutralization against all five viruses tested.

Laboratory studies on the viruses of Rift Valley fever, oncephalomyocarditis, Semliki Forest fever and yellow fever have been carried out in rodents, primates, birds and insects respectively.

The outstanding event of the year was the completion of the 120-ft. steel tower in the Mpanga Forest.
This has brought about a considerable expansion in the work on the biology of mosquitoes and other blood-sucking flying insects.

The successful transmission of virus by mosquitoes depends partly on an adequate extrinsic incubation period during which the virus multiplies in the insect and reaches the salivary glands. Thus, if a species of mosquito is short-lived in Nature, it is unlikely to take part in virus transmission, ovon though it may be an efficient ransmitter in the laboratory. It is of great importance to be able to tell the age of wild-caught mosquitoes. While this can be done in cortain spocies with considerable accuracy by dissection, it would be an advantage if such determination could be correlated with external features. Work on this problem, started in 1951, was taken up again two years ago and has been continued and extended.

\section{THE CARNEGIE UNITED KINGDOM TRUST}

$\mathrm{T}$ THE forty-sixth annual report of the Carnegie United Kingdom 'Trust, covering the year 1959 , the fourth of the present quinquennium, is largely an account of the working out of ideas, schemes and projects approved and announced some time ago*. During the year, however, the Trustees have noted signs of voluntary work being richly leavened out of all proportion to the contributions made by the Trust, but while, as publie responsibility for education at all stages has increased, the opportunities for the Trust have correspondingly diminished, the Trustees continue to find voluntary efforts that are unsupported, or inadequately supported from public funds. The quinquennial provision of $£ 50,000$ in aid of museums and art gallery dovolopment has been absorbed proportionately over the four ycars to the ond of 1959, and it seems likely that the uncommitted balance will suffice to moet claims upon it in tho remaining period. Assistance to the Museums Association was continued, but last year's grant was reduced to $£ 1,200$, in the expectation that the Association will thereby be encouraged to become self-supporting. A gratifying feature was the number of museums, earlier grant-aided by the Trust, that put in hand substantial schemes for enhancing the display of their collections and for improving their services genorally.

Much of the work of the Museums Joint Committee is concerned with improved museum lay-out, and during the year a further twenty reports were commissioned in connexion with applications for grants for methods whereby collections may be more attractively and dynamically displayed; and arising from the recommondations of these and earlier reports grants totalling $£ 9,065$ were offered to seventeen museums and art gelleries. After considering in consultation with tho Ministry of Works, the Ancient Monuments Board, the National Museum of Antiquities and the Society of Antiquaries, a proposition to rebuild a medieval structure at the north-east of the main block of Iona Cathedral to serve as a lapidarium to house the numerous historical sculptures in and around the Cathedral, the Trustees approved a grant of $£ 6,000$ to rebuild the medieval infirmary to be used eventually as a museum of cathedral

\footnotetext{
* Ciarnegie United Kingiom Trust. 46th Annual Report, 1959
} Ip. 50. (Dunfermline: Carnegie United Kingdom Trust, 1960.) treasures, but meanwhile to house the most important stones until a permanent lapidarium is provided.

Up to the end of 1959 the Trust had received 1,287 applications from the committees of pre-war village halls, serving small rural communities, for assistance in meeting the cost of renovating and equipping their premises, and of these, 1,031 , representing a total commitment of $£ 131,588$, had by that date been successful. In consultation with the Scottish Council of Social Service the Trustees have also adopted a modified seheme which will make it easier for such small communities as those on remote islands off the coast of Scotland to embark on the improvement of their halls. Grants totalling $£ 9,190$ were promised during the year towards the building of five now village halls in Eire, and undor the scheme for providing film projectors and screens for the use of crofting communities, oquipment was installod or is about to be installed in thirteen places in the Highlands. A review of progress in the seven schemes for oxtending into rural areas the advico services available in urban districts through the Citizens' Advice Bureaux, indicates that the experiments have been worth while and the sorvices will bo continued when the Trust's grant terminates. The committee set up to study and discuss the development problems of new eommunities also made sutisfactory progress, and the report emphasizes the primary need for leadership in such communities. The National Federation of Community Associations was promised a grant of $\$ 5,500$ to finance a two-year project for training full-time community centre wardens. The first group of trainees completed their course in March 1959, and a second group started a similar course in the autumn of 1959. Annual grants were also made to the various national councils of social service, and a grant of $£ 6,500$ in annual instalmonts towards the establishment of the North Ireland Association for Mental Health, a like amount being provided by the Government of Northern Ireland. A grant of $£ 2,500$ over the first two years was offered towards the cost of an experimental publicity campaign for three years by the Liverpool United Voluntary Organization for the maintenance of voluntary social service.

In education, the Trust supported 173 bursaries, totalling £454, with tho Fiold Studios Council 